\title{
Euro-Mediterranean Partnership
}

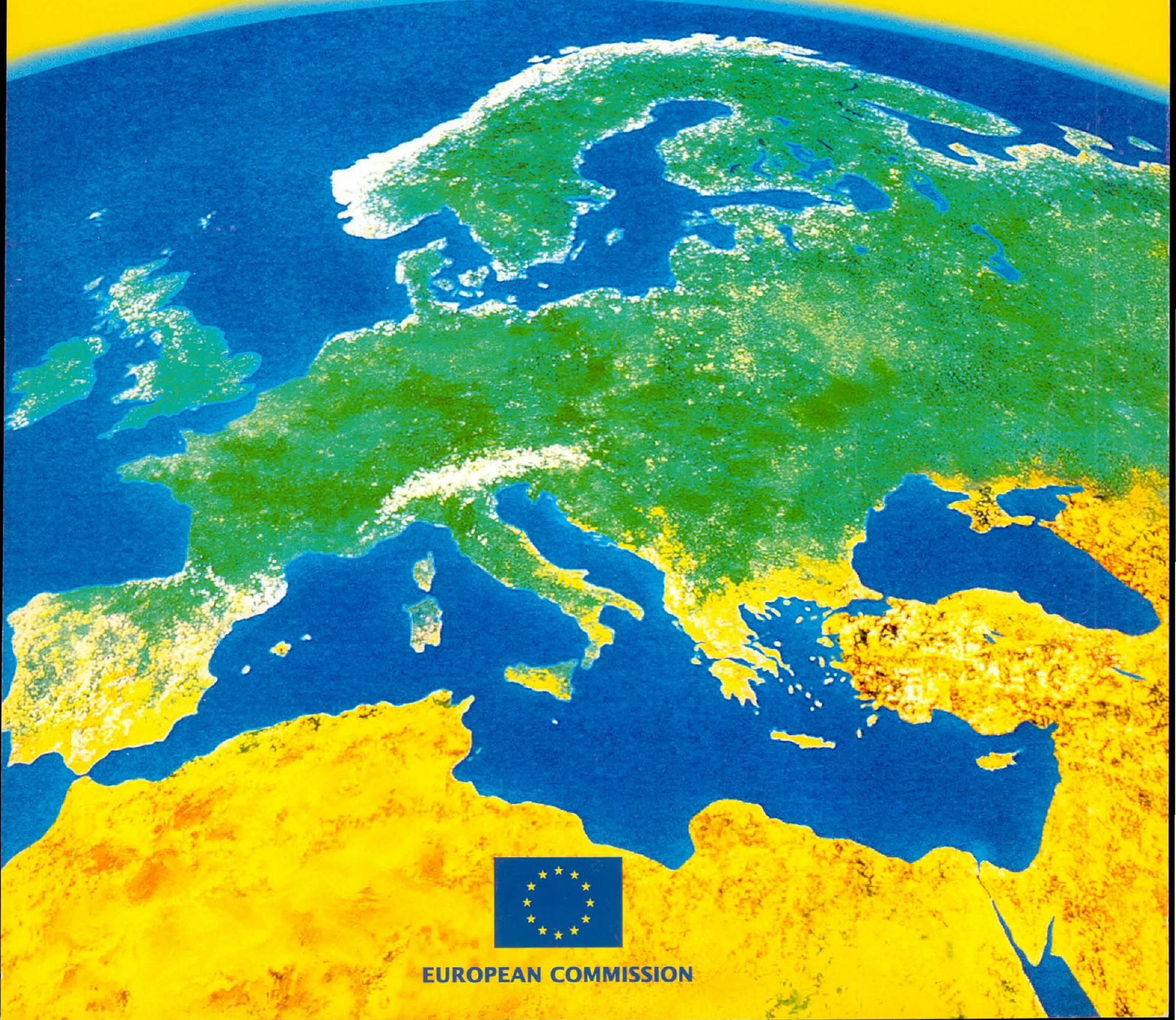


(c) Copyright European Commission. Directorate General 1B External Relations, May 1998.

Text: Bernard Delpuech. The content of this brochure does not necessarily reflect the official views of the European Commission. Design and production by Karakas. 


\section{Euro-Mediterranean}

Partnership

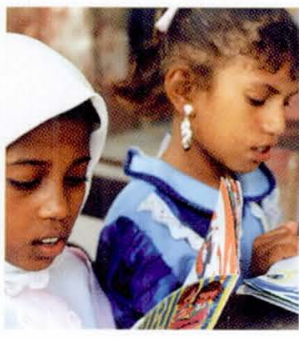

\section{From aid to partnership}

New context and challenges

The strengthening of Euro-Mediterranean links

\section{Barcelona: an innovatory partnership}

Ambitious goals

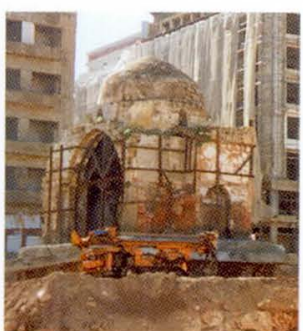

A new approach

A global dimension

Two complementary approaches

Increased finance

\section{Partnership on the ground}

\section{A forum for political and security dialogue}

Towards a Euro-Mediterranean Stability Charter

Internal stability: promotion of democracy and human rights

The European Union, the largest donor in the Middle East peace process

\section{Support for liberalisation and economic reforms}

Gradual establishment of a free trade zone Support for development of the private sector Actions in favour of an improved social balance The contribution of the regional partnership

\section{Strengthening the links between civil societies}

Actions to encourage improved mutual understanding Development of exchanges between civil societies: the programmes of decentralised cooperation 


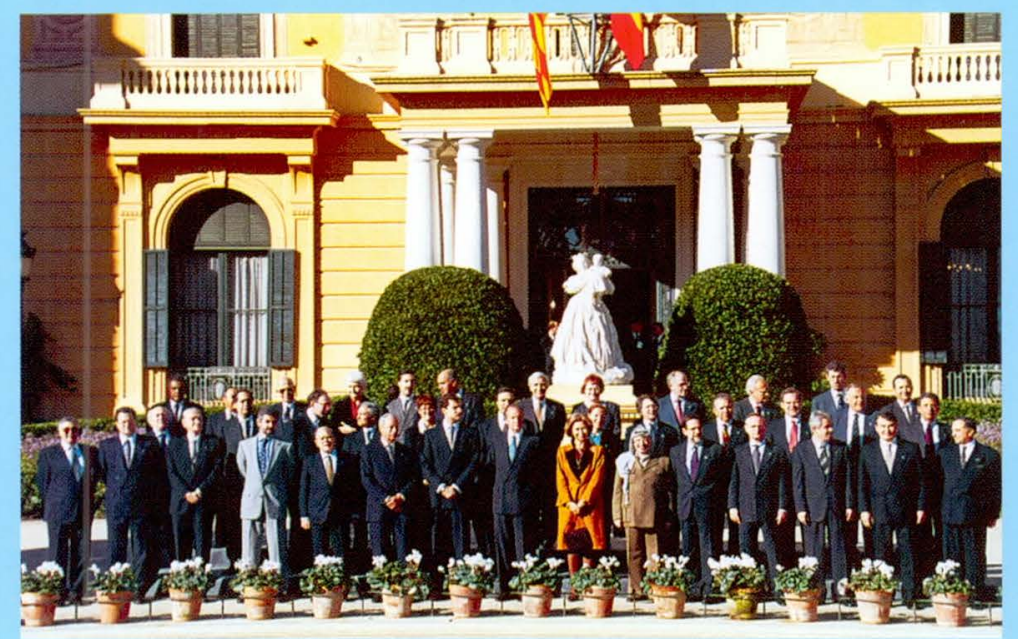

\section{Foreword}

The Euro-Mediterranean Partnership was established at the Euro-Mediterranean Conference of Ministers of Foreign Affairs held in Barcelona on November 27-28, 1995. It is a joint initiative by 27 Partners, an ambitious initiative which will remain in history as the first attempt to create durable and strong bonds between the shores of the Mediterranean.

This is obviously a difficult endeavour in the current regional political context, but also a necessary ambition. Necessary for the European Union which cannot maintain its prosperity and deepen its integration without stability and prosperity in its immediate neighbourhood. Necessary too for the Mediterranean Partners who expect from the Union not only market access, investment and transfers of know-how, but also a better understanding as regards culture, civilization and human affairs.

This brochure has a modest objective: to explain the bases, the objectives and the content of the Euro-Mediterranean Partnership and, above all, to illustrate its daily life through a few concrete examples. 


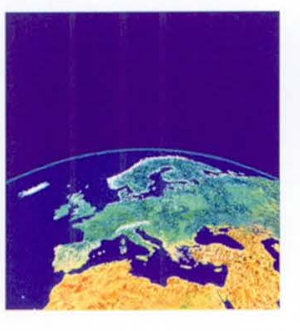

\section{From aid \\ to partnership}

Major changes marked the start of the 1990s, requiring a strengthening of relationships between Europe and the Mediterranean. Several factors caused awareness to be raised in Europe of the urgency of Mediterranean issues, and of the need to organise a

\section{Euro-Mediterranean area.}

\section{New context and challenges}

- The fall of the Berlin Wall, in November 1989, overturned Europe's geo-political and strategic landscape. The application by several central European countries to join the European Union was justification for a re-balancing of relations of the European Union southwards. Several Mediterranean countries also wished that a new impetus be given to their relations with the European Union.

- Globalisation and regionalisation have become two characteristics of the world economy. The constitution of regional economic groupings is outlining a new economic map for the planet. Against a background of growing interdependence, the Mediterranean countries risk becoming the also-rans of the new economic world order if they are not associated with Europe.

- Imperatives of peace and security imply that the growing gap between Europe and the Mediterranean countries should be minimised. Income differences, currently standing at 1 to 12 , would increase to 1 to 20 by 2010 if no measures were taken to support the economic development of the Mediterranean countries, whose population, at 220 million in 1995, will grow to more than 300 million by 2010 .
- The policy undertaken during the 1970s and 1980s by the European Community at that time, in relation to the Mediterranean countries followed a traditional approach, based firstly on trade concessions, and a policy of financial cooperation, based in the main on traditional project aid. These actions have proved insufficient to sustain the economic progress of the non-EC Mediterranean countries.

\section{The strengthening of Euro-Mediterranean links}

The construction of Europe cannot take place without taking account of the neighbourhood in which it finds itself, both to the east and to the south.

The need to implement a bolder policy, better able to respond to the challenges that the Mediterranean countries must meet, and to build with them a common destiny, had already led the European Community to re-assess the terms of its cooperation policy. In 1992 this orientation led to the implementation of the Renovated Mediterranean Policy (RMP).

Given the inappropriateness of traditional methods of cooperation, the RMP introduced several innovations:

- the financial effort for the period 1992-1996 increased by $50 \%$ compared with the resources contained in the previous financial protocols;

- a major qualitative leap forward was achieved with the launch of a regional cooperation policy;

- by means of programmes of decentralised cooperation which go to the very heart of civil 
society, the path to a genuine partnership relationship was opened up.

Support for structural adjustment was introduced for certain Mediterranean countries engaged in a process of liberalisation and economic reform.

This idea of a global partnership, which was mentioned for the first time in the European Council meeting of Heads of State and Government in Lisbon in 1992, was confirmed and given greater substance by the European Council in Corfu in June 1994, and in Essen in December 1994. The European Council meeting in Cannes, in June 1995, endorsed the proposals of the European Commission recommending "the establishment of a Euro-Mediterranean partnership".

Finally, the Euro-Mediterranean conference in Barcelona, in November 1995, laid the foundations for a new regional grouping, and marked a turning-point in Euro-Mediterranean relations. The participants in this conference - the 15 member states of the European Union and the 12 Mediterranean partners, represented by their Foreign Ministers ${ }^{1}$, the Council of the European Union and the European Commission adopted a declaration containing the guidelines for this partnership, and approved a work programme in order to guarantee its concrete application.

Having thus established a common basis to instigate a process of global cooperation, the 27 partners who adopted the Barcelona declaration opened the way to a process of dialogue and regional cooperation.

(1) European Union: Belgium, Denmark, Germany, Greece, Spain, France, Ireland, Italy, Luxembourg, Netherlands, Austria, Portugal, Finland, Sweden, United Kingdom.

Mediterranean partners: Algeria, Cyprus, Egypt, Israel, Jordan, Lebanon, Malta, Morocco, Syria, Tunisia, Turkey, Palestinian Authority.

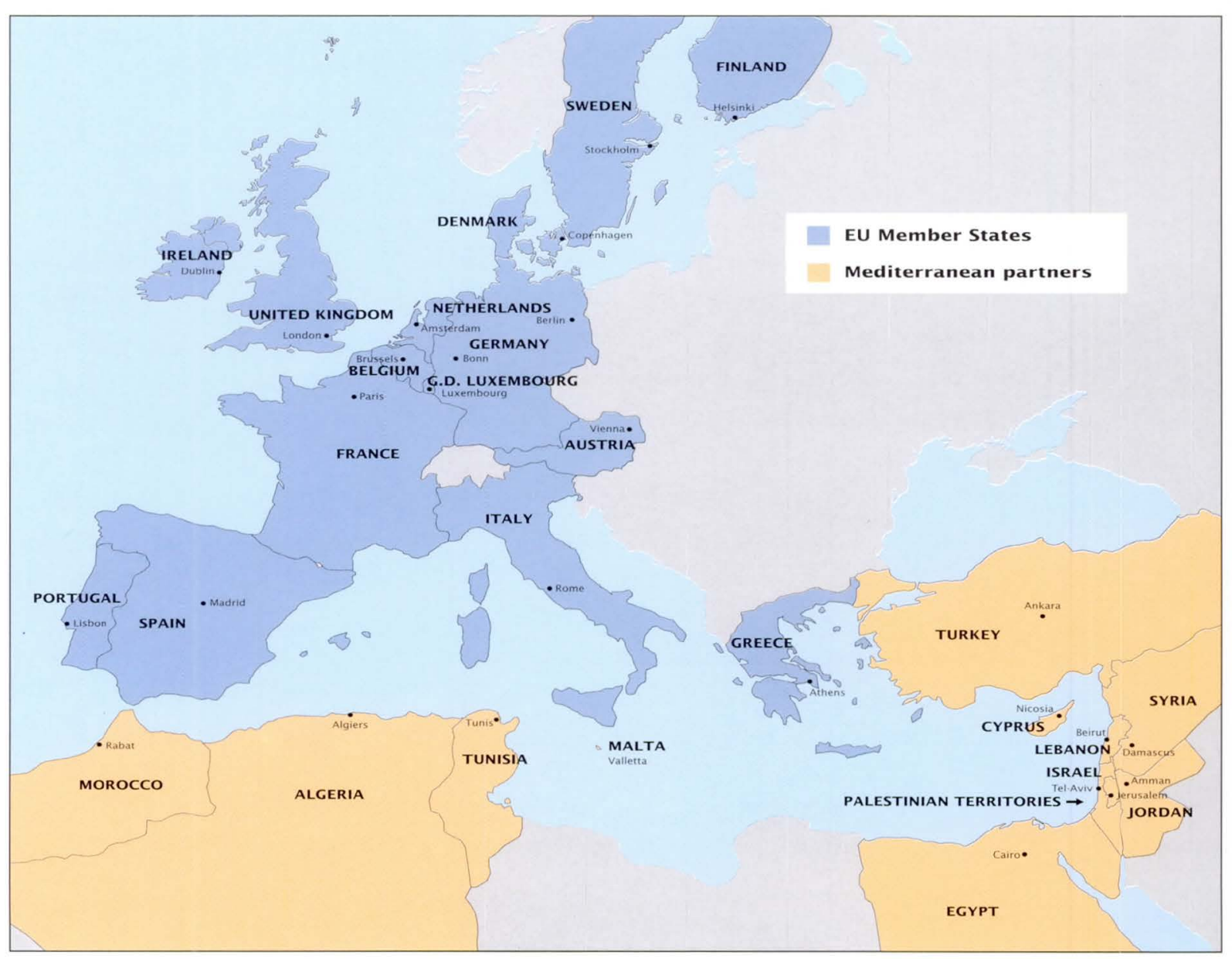




\section{THE ESSENTIAL ASPECTS OF THE EURO- MEDITERRANEAN ASSOCIATION AGREEMENTS}

In bilateral terms, the Euro-Mediterranean Partnership takes the form of a series of Association Agreements between the Mediterranean partners and the European Union. Three agreements have been signed, with Tunisia on 17 July 1995, Israel on 20 November 1995 and Morocco on 26 February 1996. Negotiations began with Egypt, Jordan and Lebanon in 1995, and with Algeria. An Interim Agreement with the Palestine Liberation Organisation on behalf of the Palestinian Authority was signed on 24 February 1997.

Cyprus and Malta, which had already been linked to the Union by Association Agreements since 1973 and 1971 respectively, are candidates for membership. Turkey entered into a Customs union with the European Union in January 1996.

These new Association Agreements were signed for an unlimited period, and replace the Cooperation Agreements signed in the 1970s. Each agreement reflects the global nature of the relationships between the Mediterranean partners and the European Union.

\section{Basic principles}

Respect for democratic principles and fundamental human rights are considered to be an essential element of the agreements.

\section{Political dialogue}

Regular political dialogue is instituted between the parties and relates to all subjects of common interest, notably peace, security and regional development.

\section{Free circulation of goods}

For each of the Mediterranean partners, the agreement provides that free trade shall gradually be implemented over a transitional period of 12 years maximum from the entry into force of the agreement.

In the case of industrial products originating from within the Union, Customs duties applicable to imports to the Mediterranean partner shall gradually be eliminated over the 12-year transitional period. Exports to the Community of industrial products originating in the Mediterranean partners which are signatories to the agreements, continue to benefit from the pre-existing free trade regime.

In the case of agricultural products, the agreement provides for a gradual liberalisation through a widening of preferential measures already in application, and a re-examination of the situation in the year 2000 .

\section{Economic cooperation}

Regular economic dialogue is instituted between the parties and covers all fields of macro-economic policy. Various sectors for collaboration are planned (environment, energy, tourism, etc.), for which the agreement sets the goals and priority fields of action.

\section{Social and cultural cooperation}

Dialogue is instituted in the social field. The agreement specifies high-priority actions, such as, for example, promotion of the role of women. The aim of cooperation in the cultural field is to achieve better comprehension of the respective cultures.

\section{Financial cooperation}

In all cases, except for Israel, appropriate financial aid is provided, to implement, through the MEDA programme, the various aspects of the agreements.

\section{Institutional arrangements}

An Association Council enables the Union and all Mediterranean partners which are signatories to the agreements to meet regularly at ministerial level. 


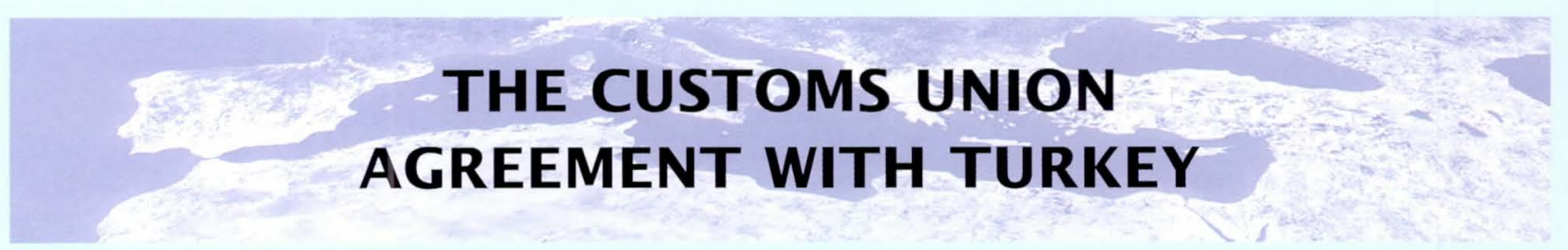

Following the agreement which came into force on 31 December 1995, Turkey is the first Mediterranean partner to enter into a Customs union with the European Union, its main trading partner, with which it conducts half its trade. Turkey thus completes a process begun in 1963 with the European Community.

The Customs Union constitutes a logical extension of the adjustment effort undertaken by Turkey since the start of the ' $80 \mathrm{~s}$. Throughout these years, Turkey successfully benefitted from trade preferences with the Community, as demonstrated by the predominant share (over $70 \%$ ) of manufactured products in its exports.

\section{Immediately applicable measures}

- Elimination of Customs duties, taxes with equivalent effect and quotas for industrial products, including textiles;

- Application by Turkey of the common customs tariff and Community Customs legislation;

- Adoption of the entire Community trade policy regime;

- Adoption of Community competition law with, in particular, the setting up of a competition authority and the application of mechanisms relating to State aid;

- Adoption of Community law in the field of intellectual, industrial and commercial property.

\section{Gradually applicable measures}

- Application over 5 years of preferential measures that the Community grants to partners with which it is linked by an Association or Cooperation Agreement;

- Removal over 5 years of technical obstacles to trade, in accordance with Community law;

- Adoption over 2 years of Community provisions relating to State monopolies;

- Between now and 1 January 1999, Turkey must ensure the patenting of pharmaceutical processes and products.

\section{Financial support}

To support the efforts made by Turkey to adapt its economy to the Customs union, the Community has provided for (starting in 1996 for 5 years), a financial aid package of 375 million Ecu supplemented by loans from the European Investment Bank.

\section{ISRAEL, A SCIENTIFIC AND TECHNOLOGICAL PARTNER OF THE EUROPEAN UNION}

On 29 March 1996, the European Union and Israel signed a Scientific and Technological Cooperation Agreement, in which, for the first time, a non-European industrialised country is associated with the Community's Framework Programme for research, technological development and demonstration actions.

Based on the experience acquired since 1983, of a substantial set of relationships, the Agreement of 29 March 1996 broadens and deepens the framework of this scientific cooperation. This is in line with the logic of the Association Agreement signed on 20 November 1995 between the European Union and the State of Israel, which provides for an intensification of scientific and technological cooperation.

The agreement provides for:

Participation of Israeli research organisations (Universities, industrial companies and individuals) in the activities of the fourth Research and Development
Framework Programme of the European Union, excluding the nuclear sector;

In exchange, the possibility for European research organisations to participate in Israeli research programmes in subjects equivalent to those of the fourth Framework Programme;

A financial contribution by Israel to the budget of the EC R\&D Framework Programme, in proportion to its GNP relative to that of the European Union, i.e. approximately $1 \%$. 


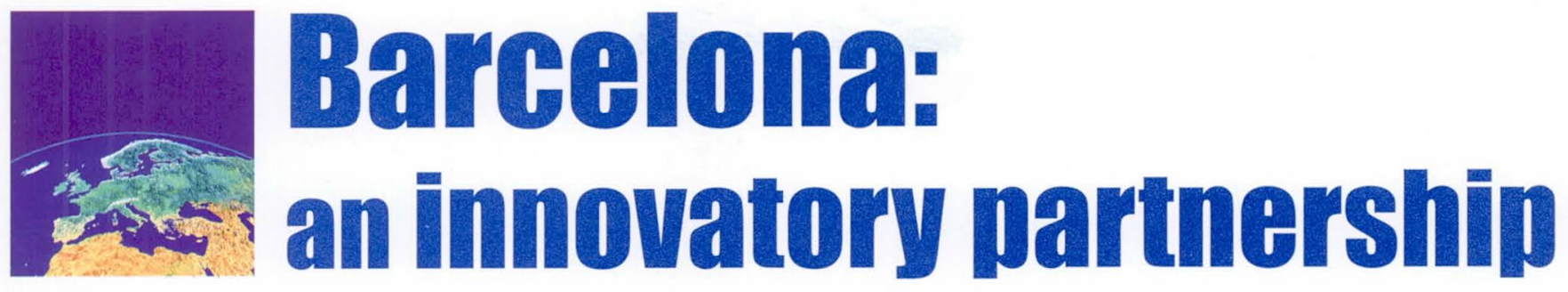

\section{Ambitious goals}

\section{The Euro-Mediterranean partnership was unanimously} approved by the 27 Foreign Ministers present in Barcelona, which gives it a special force.

This high profile geo-political project is based on three goals:

- definition of a common area of peace and stability through a reinforcement of political dialogue and security;

- construction of a zone of shared prosperity through an economic and financial partnership, and the gradual establishment of a free trade zone, in order to integrate the Mediterranean partners in the major economic system in the region, that of the European Union;

- a rapprochement between peoples through a social, cultural and human partnership, aimed at encouraging understanding between cultures and exchanges between civil societies.

The 15 member states of the European Union are committing themselves to a policy of the Mediterranean, and no longer for the Mediterranean, the main goal of which is to reduce the gap between the neighbours to the north and south of the Mediterranean.

Barcelona opened the way to a process aimed at intensifying, at all levels, relations between the European Union and the Mediterranean partners. This process will be successful only if the partners directly concerned by the future of relations between Europe and its Mediterranean partners - public authorities, business communities, researchers, teachers and all those with responsibilities in civil society - take an active part in answering this challenge.

\section{A new approach}

The partnership adopted in Barcelona introduces a totally new spirit in relations between Europe and the Mediterranean partners. An authentic partnership has been put in place, consisting of openness, prior dialogue and work in common, from the design of policies until their implementation stage. The preoccupations and interests of each of the partners are taken into account in a relationship of equality. Respect for these principles, which was the basis of the success of the Barcelona Conference, is the basis for the future progress of the partnership.

\section{A global dimension}

The previous cooperation policies of the European Union consisted of relatively limited economic and financial aspects. The partnership, however, now applies to a broader range of themes. In addition to the economic and financial fields, there are two new elements in Euro-Mediterranean relations: the political and security field, and social, cultural and human questions.

The Mediterranean partners wish to have a balanced dialogue with the European Union, relating not only to economic questions. They also wish to gain support in the political and security fields, given that they provide $20 \%$ of the Union's energy requirements, sell half their exports to it $(2 / 3$ in the case of the North African states), and purchase half their imports from it. The Euro-Mediterranean partnership takes account of these major relationships of interdependence, and acknowledges the global nature of relations between the Union and its neighbours to the south.

For the first time, the European Union and the Mediterranean partners regard dialogue between their cultures and their civilisations as one of the essential themes of the partnership. 


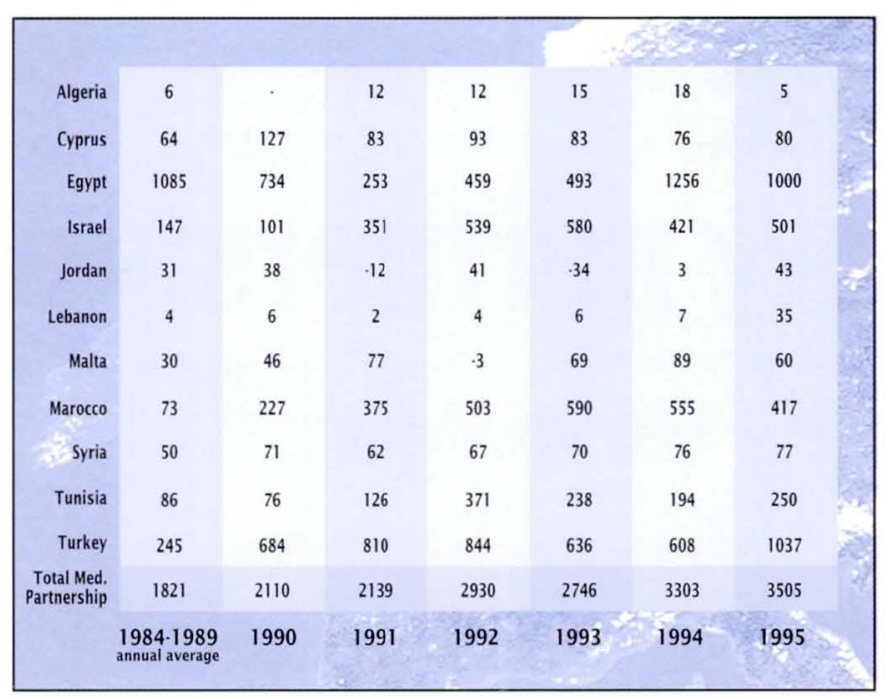

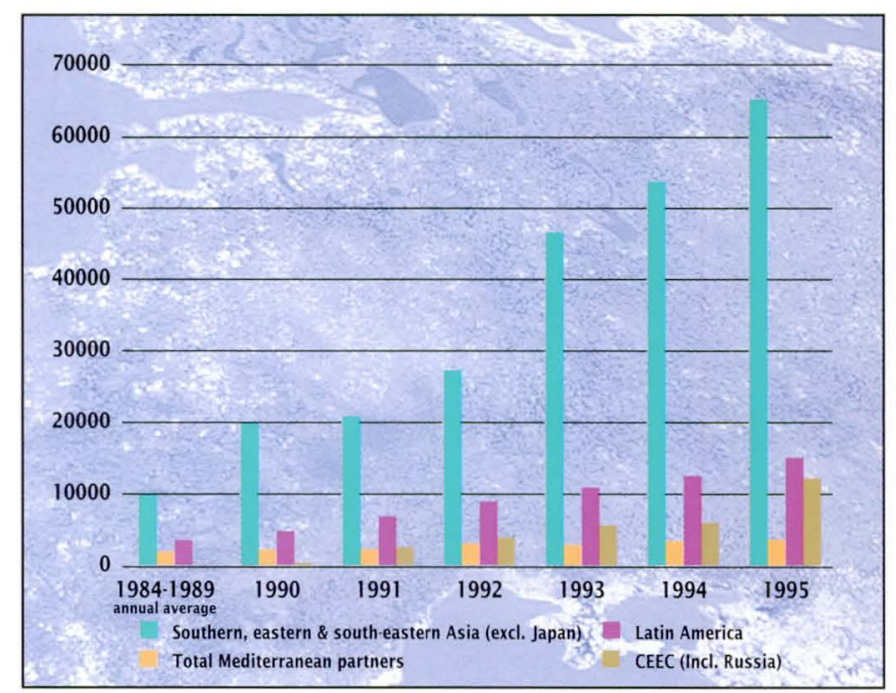

Foreign direct investments in the 11 Mediterranean partners between 1984 and 1995 (millions of dollars) Sources: Report on worldwide investment (UNCTAD, September 1996)

Also for the first time, the Mediterranean partners have expressed the feeling that they are recognised in terms of respect for their identities, and no longer simply as markets, energy suppliers or sources of immigration. This new element has a strong symbolic significance at a time when the perception of the irreconcilable nature of cultures is growing.

Conversely, the 27 partners assert that the renewal of cultural dialogue is as essential as political and economic cooperation in order to fill the growing gap which, over recent times, has opened up between their peoples. The fundamental recognition of the cultural dimension is intended to reverse this trend, by discouraging on either side the attitudes of rejection based, more often than not, on ignorance or prejudice. The overall aim is to make the Mediterranean an area of contacts, in order to prevent it becoming a frontier for confrontation.

This global dimension is also found in terms of those involved at the grass roots. By giving civil society and the private sector major roles, the Euro-Mediterranean partnership is no longer limited to governments and public institutions alone, but becomes something which concerns everyone. In this sense, the partnership reflects the development of societies and of methods of cooperation at an international level.

\section{Two complementary approaches}

Two complementary approaches have been chosen to implement the Euro-Mediterranean partnership.
On a bilateral level, the Euro-Mediterranean Association Agreements which already exist or are in course of negotiation between the Union and each of its partners account for most of the financial resources. Whilst adopting all the principles underlying the new Euro-Mediterranean relationship, these agreements also reflect the characteristics specific to relations between the EU and each of the Mediterranean partners.

On a regional level, dialogue constitutes one of the most innovatory aspects of the partnership. The 27 partners have adopted a work programme which sets out the actions and priorities which are implemented through regional, regular and global dialogue, relating to the political, economic and cultural fields. By this means, a permanent dialogue is established, with the Mediterranean as the central theme of the discussions.

This multilateral dimension of Euro-Mediterranean relations complements the bilateral actions and dialogues taking place in relation to the Association Agreements. Discussion among the 27 is most useful for:

- addressing themes of common interest and deciding on joint projects;

- strengthening habits of working together between the partners, both in terms of government and of private operators;

- developing a genuinely authentic partnership, based on a relationship of equality, and no longer one of donor to beneficiary. 

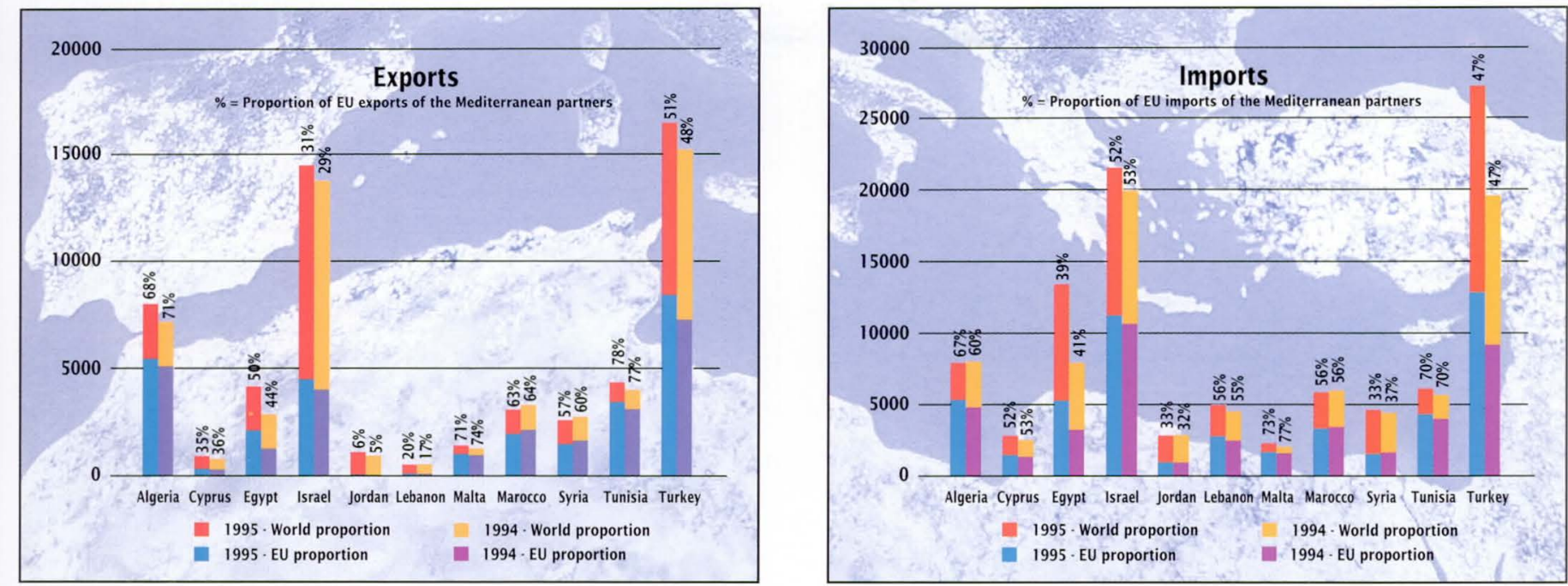

Proportion of EU and world in imports and exports of the 11 Mediterranean partners between 1994 and 1995 (millions of dollars) Sources: Report on worldwide investment (UNCTAD, September 1996)

Working procedures have now been established. The Euro-Mediterranean Committee for the Barcelona Process, consisting of the troika of the European Union and each of the Mediterranean partners, meets on average every three months to decide on actions to be undertaken under the work programme. The European Commission prepares and manages the monitoring of all the regional partnership work. Every six months, on average, two sectoral ministerial meetings, and five meetings at expert level, are held.

\section{Increased finance}

The European Council which met in Cannes in June 1995 set the amount of the financial aid package with the Mediterranean partners at 4,685 million Ecu for the period 1995 - 1999. With the addition of loans from the European Investment Bank (EIB) to the budget funds, the finance devoted by the European Union to the Mediterranean partners should reach approximately 2 billion Ecu per year, representing a substantial increase, compared to resources committed between 1992 and 1996. The MEDA programme, counterpart of the PHARE programme established with the countries of central and eastern Europe, covers all the fields of the partnership, and relates both to bilateral actions, which will receive approximately $90 \%$ of the funds, and to regional projects of joint interest, identified within the process of regional dialogue, and those of decentralised cooperation.

The MEDA Regulation, which was adopted by the Council of Ministers of the European Union in
July 1996, sets out the management procedures for the programme, and replaces the rules in force under previous financial protocols signed with each country.

A major innovation of the MEDA programme relates to the methods for allocating credits. Projects are now subject to the principle of annual budget allocation. They must thus be committed before the end of each budget year.

A second innovation introduced by the MEDA programme relates to programming with each beneficiary country, which is indicative. The European Commission sets out a three-yearly framework with annual modifications. The programming has a large degree of flexibility to take account of progress achieved in implementing the programme, and the development of priorities.

These innovations are, in fact, the logical consequence of the partnership's new political framework. It is no longer a question solely of providing aid for one-off projects, but of support for a global reform policy which must progress at a jointly-decided pace. The principle of annual credits which are not renewed if they are not used will stimulate the progress of reforms. In addition, the flexible nature of the threeyearly indicative programmes has the advantage of being a strategic procedure; it enables projects to be conceived over a long period, whilst at the same time adapting financing to the conduct of reform processes; it is thus a guarantee of efficiency in accompanying these reforms. 


\section{TRAINING OF DIPLOMATS}

In its first meeting in April 1996, the Euro-Mediterranean Committee for the Barcelona Process decided to entrust the bi-annual organisation of information and training sessions relating to the Euro-Mediterranean partnership to the Mediterranean Academy for Diplomatic Studies, Malta. These sessions are open to diplomats from the $\mathbf{2 7}$ partners with responsibility for dealing with Euro-Mediterranean questions.

This information and training programme, which is organised with the support of the European Commission, is intended to improve the understanding of diplomats from the Mediterranean partner countries of the way in which the European Union operates, and more specifically of aspects relating to the Barcelona process. It also permits contacts between diplomats participating in it, who will, during their careers, be called upon to play a major role in implementing the EuroMediterranean partnership.

The first session, for young Euro-Mediterranean diplomats, was held from 26 September to 6 October
1996. A second seminar, for more experienced diplomats, took place in Malta in March 1997.

In addition, as a complement to this programme, the Mediterranean Academy of Diplomatic Studies, with the support of the European Commission, established the "Euromed Internet Forum" server, which is a source of information concerning the Euro-Mediterranean partnership designed to respond primarily to the requirements of the Foreign Ministries of the twentyseven partners.

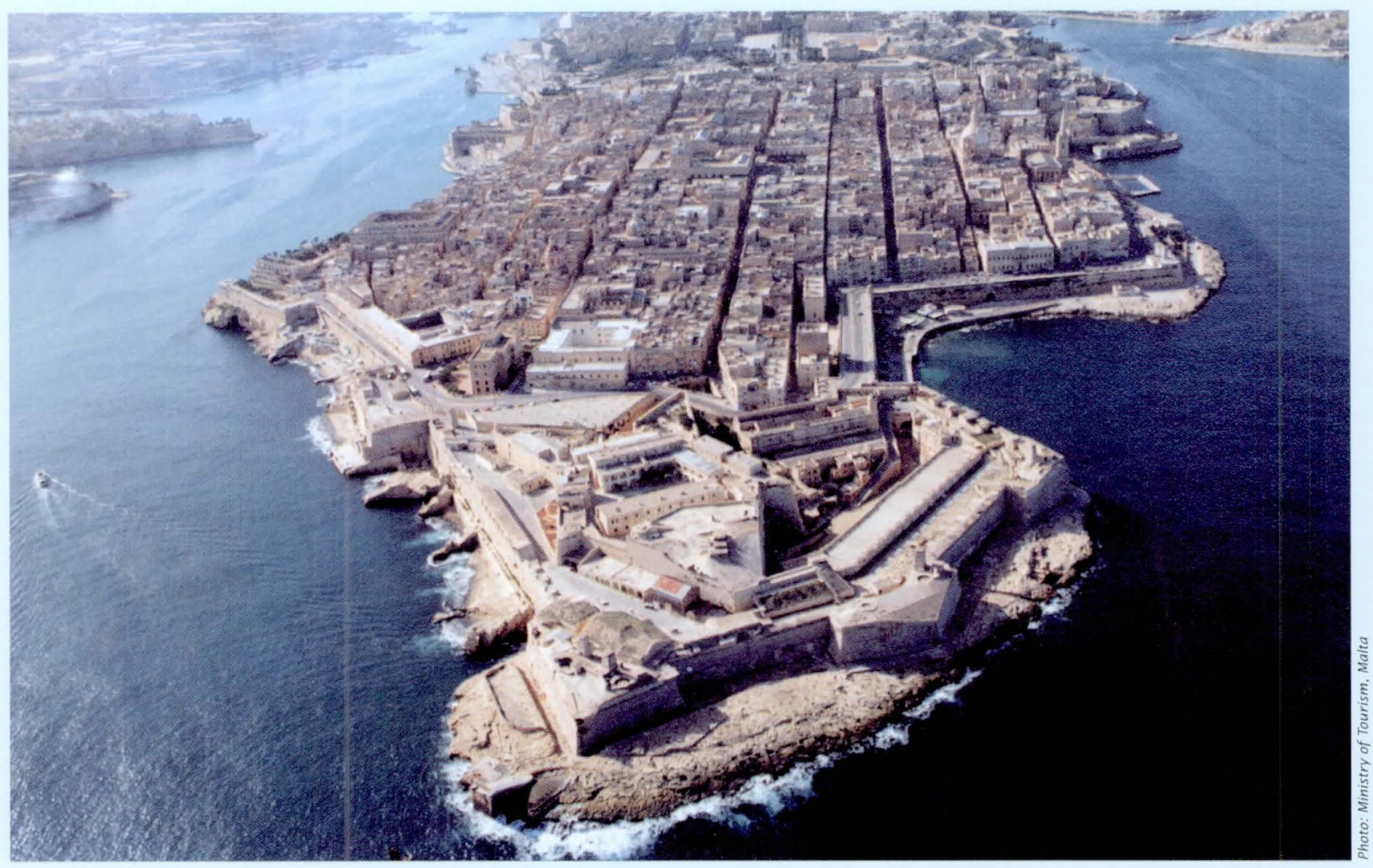

The second Euro-Mediterranean Conference of Ministers of Foreign Affairs was held in Valletta, Malta, in April 1997. 


\section{EUROPE, THE FIRST PARTNER OF THE PALESTINIANS}

The Oslo declaration, in September 1993, followed by the establishment of a Palestinian Administration in a part of the Occupied Territories, gave a new boost to cooperation between the European Union and the Palestinians. With the aid provided by the member states, the European contribution accounts for one third of the international support for the Palestinians, putting it easily in first place among donors to the development of the West Bank and the Gaza Strip.

In programming this aid, the European Commission applies in particular, the priorities defined by the Palestinian Authority. Since the Barcelona Conference, the Palestinian Authority has become a full partner of the European Union.

\section{Improvement of economic and social} infrastructures

The European Union is concentrating its action on the rehabilitation of infrastructures in the following fields: education, health, public services, and urban authorities.

\section{Support for the private sector}

The European Commission is implementing a programme for the development of the private sector which provides concrete assistance to companies to develop their commercial activity with the aim of meeting local demand and increasing their export capacity. A Palestinian business support centre has been established in Ramallah, which coordinates a programme for consultation, information and training.

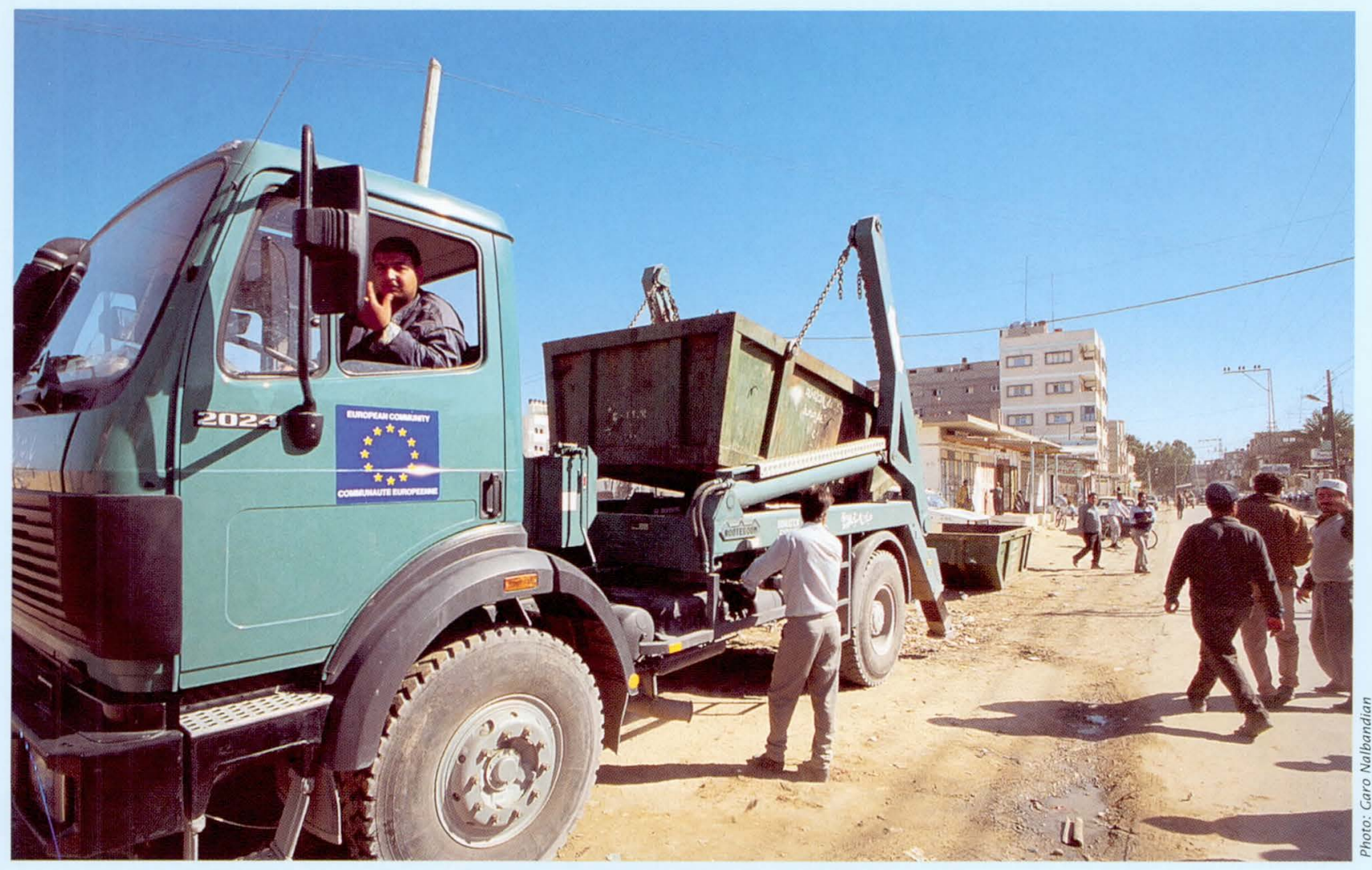

Solid waste collection project in Gaza. 


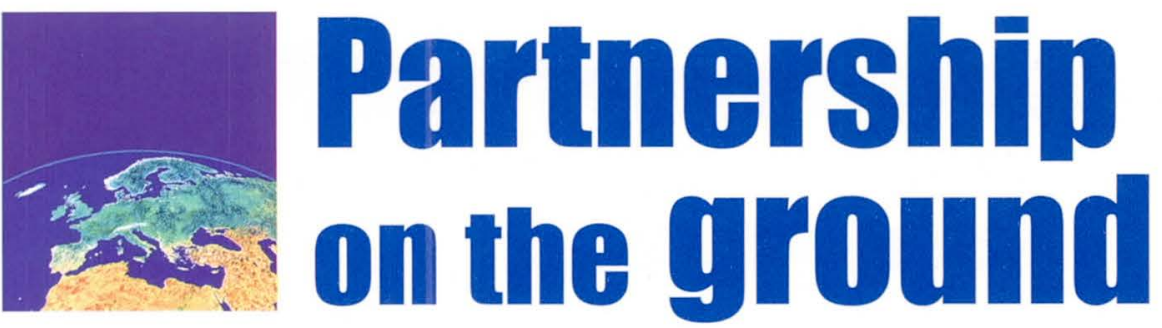

\section{A forum for political dialogue and security}

\section{Towards a Euro-Mediterranean Stability Charter}

In addition to the bilateral political dialogue, the partnership established at the Barcelona Conference adds a multilateral dimension, establishing a place for global political discussion where, for the first time, the Mediterranean is at the centre of discussion. The need for such a political dialogue originates from the acknowledgement that the stability and prosperity of the European Union are indissociable from those of its immediate neighbours to the south.

This political partnership on a regional scale relies on a pragmatic approach. It has set itself the goals of creating a sustainable climate of cooperation through the establishment of mechanisms for preventing crises and for developing habits of dialogue and work in common. Such dialogue should improve the climate for resolving conflicts in the region, but is in no sense intended to replace the specific conflict resolution mechanisms already in force.

The senior civil servants with responsibility for this dialogue regularly meet to discuss, above all, confidence and security building measures leading to the establishment of a Stability Charter. To reinforce this political and security dialogue, a network of Foreign Policy Institutes has also been established.

\section{Internal stability: promotion of democracy and human rights}

The 27 partners who signed the Barcelona declaration committed themselves to respect a number of principles. In particular:

- to act in accordance with the United Nations Charter and the Universal Declaration of Human Rights;

- to develop a political system in accordance with international, commonly accepted norms in the area of human rights and democracy;

- to take concrete measures for the effective application of fundamental freedoms;

- to respect diversity and pluralism, and to fight intolerance, particularly racism and xenophobia, and discrimination based on race, religion and sex.

The main framework for discussion on progress of human rights and democracy is that of the EuroMediterranean Association Agreements. They provide that respect for democratic principles and fundamental human rights constitutes "an essential element" of the agreements, a clause which was not included in previous cooperation agreements.

Following the Barcelona Conference, the European Parliament decided to create the MEDA-Democracy programme to support local or regional projects aimed at promoting, in the 12 partners of the Union:

- political rights relating to democracy and the rule of law;

- civil rights such as freedom of expression, meeting and association; 


\section{SUPPORT FOR THE PRIVATE SECTOR IN TUNISIA}

On 17 July 1995, Tunisia signed the first Association Agreement with the European Union. This agreement constitutes the overall framework for actions intended to support the economic modernisation of Tunisia, with the aim of increasing the competitiveness of the productive sector with a view to establishing free trade. A more dynamic private sector is one of the essential factors for successful economic links between Tunisia and Europe.

The European Union is implementing a diversified programme:

- Creation, in Tunis, of the "Euro-Tunisia Enterprise" business centre, costing 20 million Ecu. This centre, the activities of which commenced in October 1996, supplies a range of services to private companies wishing to upgrade;

- Management of 30 million Ecu of risk capital by the European Investment Bank, available to private companies undergoing modernisation, and public companies undergoing privatisation;

- Technical assistance programme in support of the privatisation process; the Tunisian government plans to privatise 400 companies over the coming years;

- Promotion of partnerships between European and Tunisian companies already active over the past years, and reinforced in connection with the new Association Agreement, etc.;

- Support (45 million Ecu) for the programme of the Tunisian government to upgrade occupational training and training for employment, aimed at adapting the labour force for technological changes, and at encouraging the process of economic insertion and re-insertion;

- Bank training programme (6 million Ecu), intended to give Tunisia a competitive and dynamic financial system, capable of participating in the upgrading of industry;

- Promotion of foreign investments (4 million Ecu) to make Tunisia more attractive to foreign capital, and to promote Tunisian products on the world market;

- Legal and judicial centre to adapt laws and rules affected by the Association Agreement with the European Union, particularly those relating to foreign companies and investors;

- Development of micro-companies through technical assistance with training programmes given by the Professional Intervention and Adaptation Fund (FIAP).

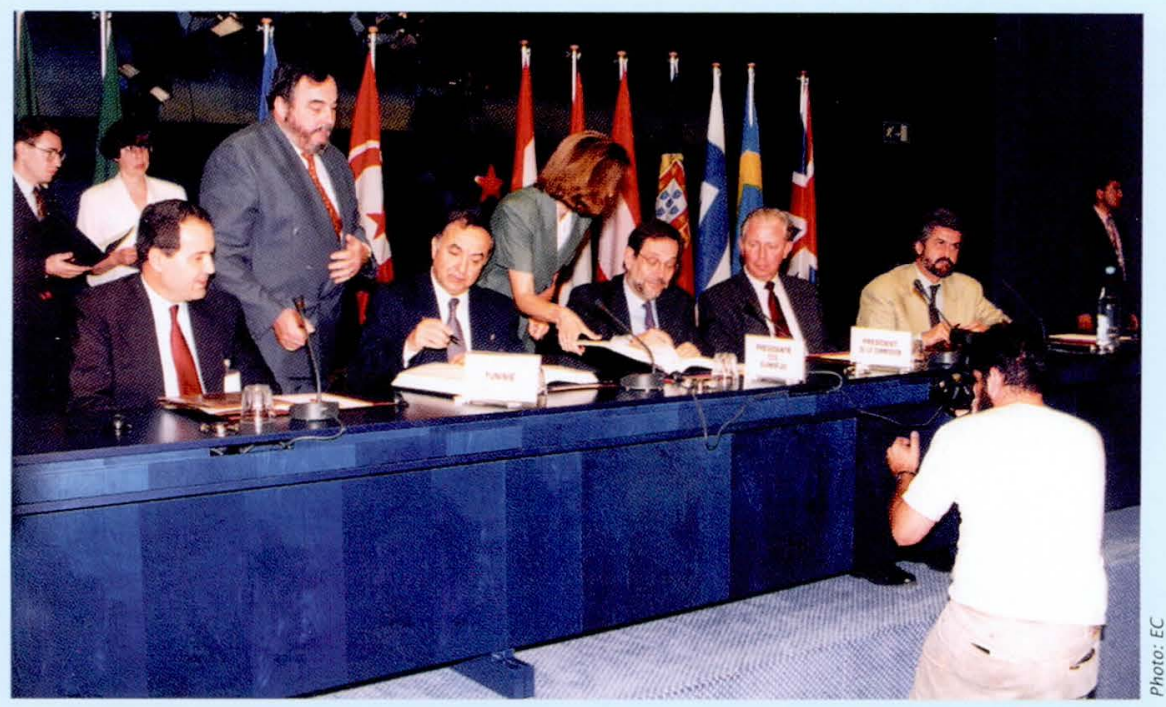

Signing of the Euro-Mediterranean Association Agreement with Tunisia in Brussels, 17 July 1995. 


\section{BUSINESS CENTRES IN THE SERVICE OF MEDITERRANEAN COMPANIES}

In order to cope with increased competition, and in order to benefit fully from free trade, companies in the Mediterranean partners must increase their competitiveness. The European Union is establishing several business centres in order to assist them do so, in the West Bank, Gaza, Egypt, Jordan, Morocco, Syria, Tunisia and, in due course, in Lebanon.

According to demand emanating from companies, and using a cost-sharing system, the services proposed by the business centres relate to consultancy, information or training. The range of proposed services includes the following:

- Commercial strategy and market analysis;

- Improvement of management and planning;

- Packaging and promotion;

- Design and development of products;

- Improvement of productivity, access to technologies and quality control;

- Export development;

- Training and management, and development of human resources;

- Financing methods and access to credit.

The information services include tools which are already operational in the European Union, such as BC-NET (Business Cooperation Network) and BRE (Company Rapprochement Office).

The centres will also encourage the development of local expertise in the company management field (advice and training services).
Strengthening the role of company groupings The development of federations and local associations of companies will be supported by the business centres in order that the private sector is able to defend its interests in its dialogue with the public authorities. The business centres assist with the networking of Mediterranean and European company groupings and Chambers of Commerce and Industry.

\section{Facilitating partnership between European and Mediterranean companies}

It is undoubtedly in this area that the business centres play a key role in their support for the competitiveness of Mediterranean companies. It is through this partnership that European technological and managerial expertise may more effectively reinforce the Mediterranean economic fabric in the form of joint companies, licences, franchising and sub-contracting contracts. The business centres complete the programmes of the European Union which are already active through ECIP (European Community Investment Partners). Many meetings have already taken place between European and Mediterranean company bosses in relation to the Euro-partnerships (in Dortmund, Bilbao, Cdansk, Glasgow, Lille and Porto), to Med-partnership (in Turkey, Morocco and Israel), or at a sector-related level through the ten or so meetings organised by MedInterprise, which have all been highly successful. 
- socio-economic rights, particularly actions aimed at supporting trade unions;

- protection of vulnerable groups such as children, women, minorities, victims of torture and prisoners.

\section{The European Union, the largest donor in the Middle East peace process}

In June 1996, the European Council in Florence once again confirmed its support for the peace process in the Middle East, and recalled the "essential principles", already expressed in the Venice declaration in 1980, aimed at establishing a just and long-lasting peace; in particular "self-determination for the Palestinians" and "exchange of land for peace, with everything this implies"; this latter principle was repeated in the Barcelona Declaration.

Although separate, the Barcelona process and the peace process in the Middle East are complementary. One of the successes of the Euro-Mediterranean partnership is to have allowed, against a tense background, dialogue to be pursued between Mediterranean partners in a context of regional meetings on all questions of common interest.

The adoption of the Oslo Declaration of Principles in September 1993, followed by the establishment of the Palestinian Authority in May 1995, led the European Union to step up its commitment in favour of the peace process, to which it is the largest donor. In particular, this commitment, took concrete form with the support given for the first elections, in January 1996, of the members of the Palestinian Council and of a Palestinian President. As early as April 1994, the European Union took sole charge of the technical preparation for the elections: censustaking, electoral preparations, civic education campaign, and provision of facilities. The IsraeliPalestinian Interim Agreement also gave the Europeans responsibility for guaranteeing that the elections were undertaken correctly: checking of electoral lists, visiting of the 1,700 voting offices by a team of 300 European observers, and participation in the vote-counting.

\section{Support for liberalisation and economic reforms}

In order to meet the economic development requirements, most of the Mediterranean partners will have, over the coming years, to achieve a high and sustainable rate of economic growth. This development will be facilitated by the liberalisation and reform of their economies.

The Euro-Mediterranean project relies on the abilities of Mediterranean businesses to undertake the necessary transformations and adaptations in order not to remain on the sidelines of development of the world economy.

The challenge is a major one for many Mediterranean partners, whose economies have for a long time been protected, and whose companies are fragile from many points of view. The approach chosen in order to take up the challenge of world competition, with Europe as a partner, seems to be the one with the best chance of success. For the Mediterranean partners, there is also an advantage of a special link with Europe in order, at one and the same time:

- to integrate their economies into the European system;

- to adapt to world competition and to the rules of the World Trade Organisation;

- to take advantage of European support in order to implement the necessary reforms;

- to benefit from effects induced by the association with the European Union, notably in relation to foreign investors.

Under the partnership, the European Union has committed itself to supporting the effort to upgrade its Mediterranean partners economically. 


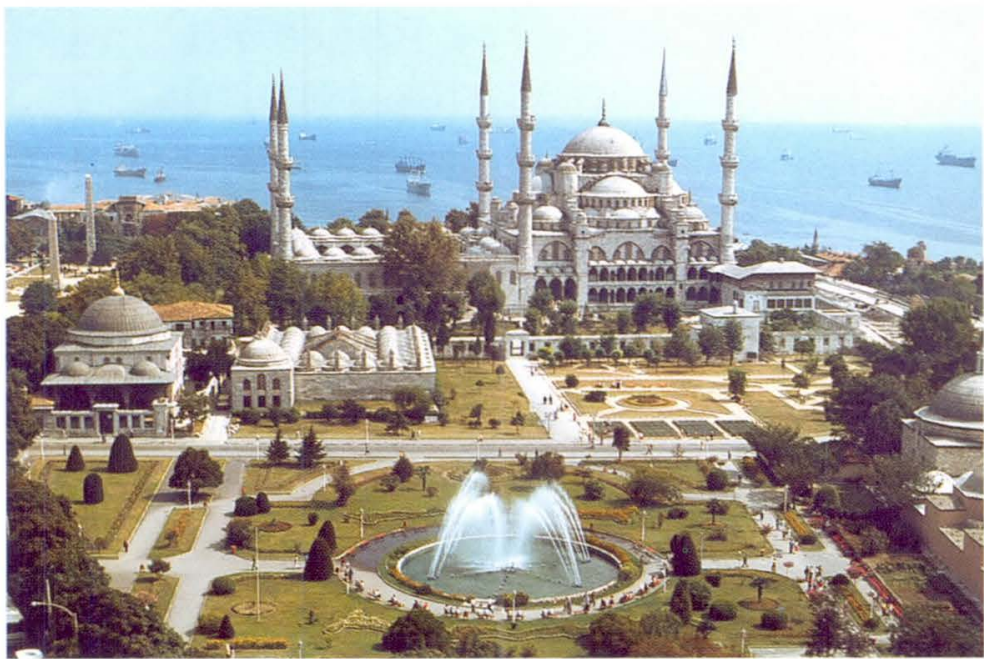

View of Istanbul.

\section{Gradual establishment of a free trade zone}

The EU and its Mediterranean partners agreed in Barcelona to establish, by the year 2010, a free trade zone in which manufactured products will circulate freely, with trade in agricultural products being gradually liberalised. The establishment of free trade is planned in each of the association agreements after a transitional period of 12 years maximum. At the end of 1996, the first milestones were in position: free trade has been established between the EU and Israel since 1989, and confirmed in the new agreement signed in 1995; Turkey entered the customs union with the EU in early 1996, and two Association Agreements have been signed, with Tunisia in 1995 and Morocco in 1996.

One of the major advantages of free trade is to enable the Mediterranean partners to enter a regional system where common rules of origin are applied. Cumulation of origin will constitute a major factor in encouraging integration and improved complementarity of the economies of the Mediterranean partners, and also the development of intra-Mediterranean trade.

The Mediterranean partners have not been left to cope by themselves with free trade. The EU is accompanying the process of tariff removal, and offering the partners a balanced set of support measures intended to soften the blow of liberalisation.

\section{Support for development of the private sector}

Whilst making allowance for the specific situations of each of the partners, and in close collaboration with them, the European Commission is implementing complementary programmes to strengthen the role of the private sector, and to encourage industrial modernisation. Eight specific goals are being pursued:

\section{- Creating a favourable environment}

Governments must provide business communities with a safe and stable environment ensuring macro-economic stability, with regulatory and fiscal regimes which are open and nondiscriminatory.

In collaboration with the member states of the Union and international institutions (World Bank, International Monetary Fund), and through an in-depth bilateral dialogue with the partners relating to macro-economic policy, the Commission is providing partners with support, and financing structural adjustment actions through direct balance of payments support. The social dimension of adjustment constitutes a characteristic of community action, which prioritises social sectors and promotes the implementation of a genuine employment policy.

\section{- Facilitating trade}

With the prospect of free trade, the Commission is supplying technical assistance in the field of harmonisation of standards, and supporting the establishment of export management instruments for the private sector.

\section{- Promoting investment}

The Mediterranean region has insufficient foreign investment. The latter plays a crucial role in the transfer of expertise and technologies. Economic growth, which the Mediterranean partners need in order to benefit from the free trade zone, depends to a great extent on their ability to attract foreign, and in particular, European investment. 


\section{THE SOCIAL DEVELOPMENT FUND IN EGYPT}

Since 1991, Egypt has been engaged in a global process of economic reform and structural adjustment aimed at strengthening the competitiveness of its economy through a disengagement of the State, where $70 \%$ of production takes place, and action to make the private sector more dynamic.

In 1993, in order to facilitate the implementation of economic transition, and to take account of its social implications, the Egyptian authorities, with the support of the international community, established a Social Development Fund (SDF) in order to meet the needs of the poorest sections of the population. The European Union is the largest donor for the period 1997 - 2000, contributing 155 million Ecu.

SDF, which is the largest programme supported by the European Union in the Mediterranean countries, responds to a dual goal: combating poverty and unemployment. To achieve these ends, three main types of action have been adopted:

- A highly labour-intensive public works programme, aimed at meeting the essential needs of the beneficiaries, especially in rural zones: irrigation and drainage canals, drinking water systems, roads, clinics, schools and social centres;

- A community development programme aimed at the people of Upper Egypt, the poorest region in the country. By relying on Non-Governmental Organisations (NGOs) the aim is to facilitate access by the most vulnerable groups, and particularly women, to certain social services: funding for income-generating activities, family planning services, and anti-illiteracy initiatives;

- A programme for development of small and mediumsized companies combining technical assistance, training and credit, aimed at facilitating the hiring of personnel.

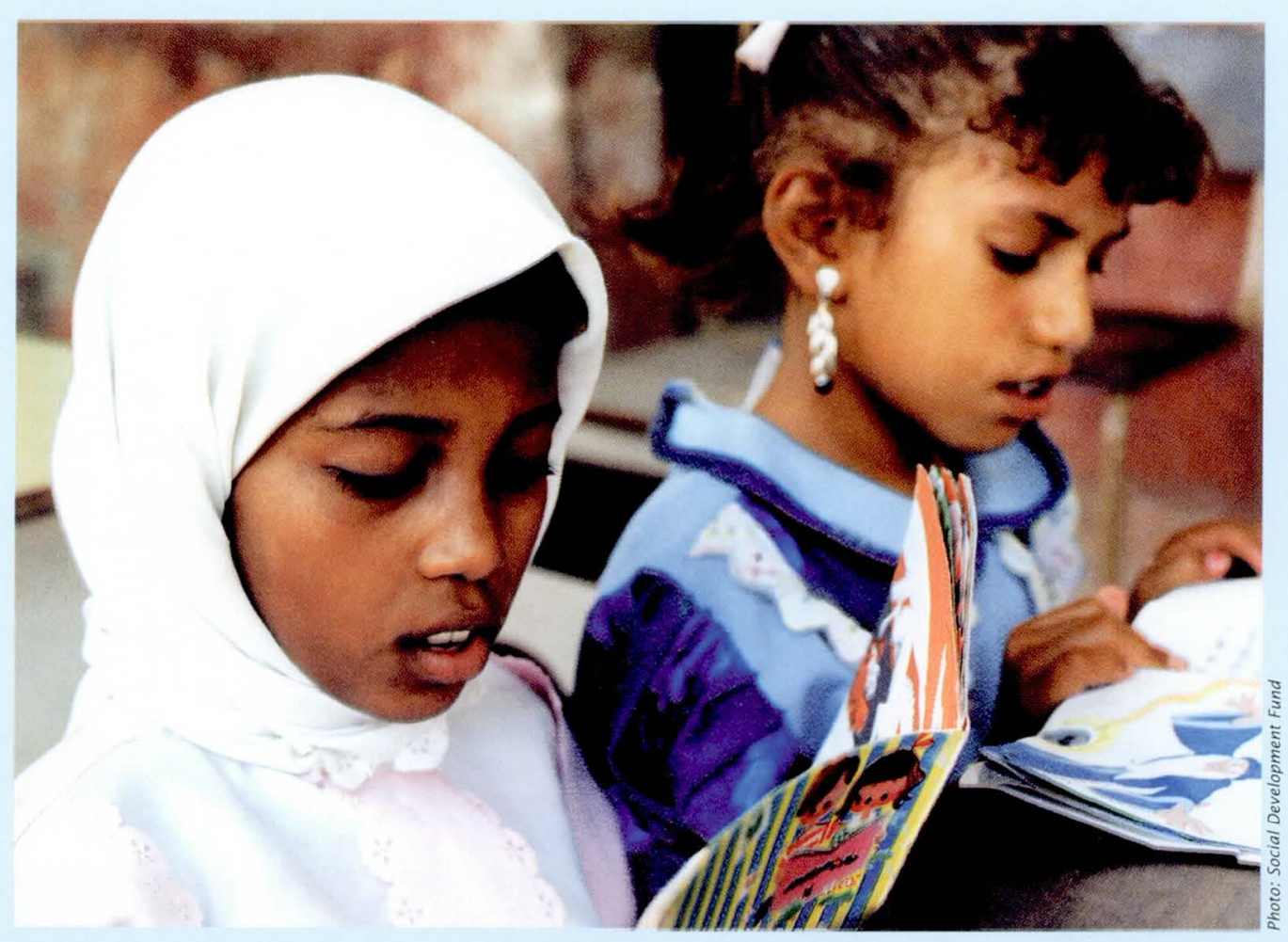

The Social Development Fund puts the emphasis on the education of girls. 


\section{SUPPORT FOR THE LEBANESE GOVERNMENT}

Fifteen years of war in Lebanon have caused considerable damage and paralysed most of the public service infrastructures due to physical destruction and the drain of skills from institutions. In 1992, the Lebanese government established a reconstruction programme, to repair the country's main public infrastructures: roads, telecommunications, electricity, schools and hospitals.

By financing studies to assess war damage, the European Commission has enabled the reconstruction to start. In addition, the European Commission has spent 30 million Ecu to support the establishment of structures to manage the emergency programme being implemented by the Council for Reconstruction and Development (CRD) of Lebanon. The aim was to give the government departments concerned the resources to enable the reconstruction programme to be brought into operation. Several indicators support the conclusion that, overall, and bearing in mind the emergency context, the goals of the programme, which should be completed in 1997, have been attained:

- The donors, and notably the World Bank, have acknowledged that reconstruction would not have started in Lebanon without the support of the European Community for the Lebanese government;
- This support gave credibility to the reconstruction programme, and enabled resources from donors to be better mobilised;

- All the management procedures, which are an essential component of the system, have been established;

- The project also helped the sectors of the Lebanese government concerned by the reconstruction to use other methods for financing public investment, such as B.O.T. (Build Operate Transfer).

Lastly, the European Commission is spending 38 million Ecu, over the period 1996-1999, to rehabilitate the whole of the Lebanese civil service.

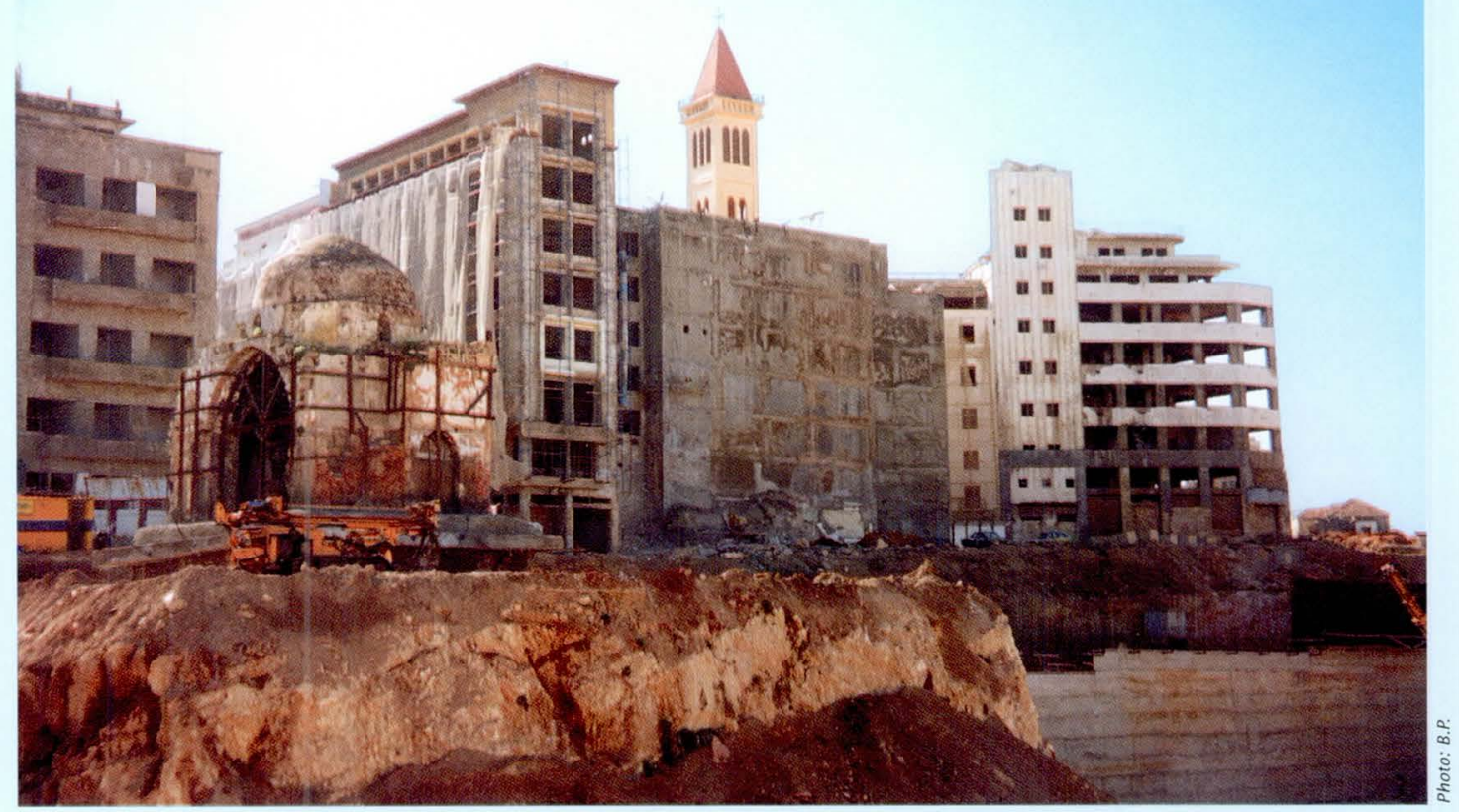

The European Union is supporting the reconstruction process in Lebanon. 
To achieve this, a simplification of laws, regulations and procedures is indispensable. The MEDA programme supplies technical assistance for a series of actions, for example to mobilise investment resources, strengthen the role of the central banks, develop effective commercial banks, create new risk capital funds and, more generally, to improve the legal and administrative framework for foreign investment.

\section{- Encouraging privatisations}

Programmes for support for privatisation have been initiated or are planned to facilitate the effective transfer of property, management and control to the private sector. The experience of the European Union in privatising telecommunications and other economic infrastructures is made available to the partners.

\section{- Improving infrastructures}

Whether in respect of electricity, water, or communications, these services are essential to the competitiveness of companies. In order to reduce costs and improve the quality of infrastructure companies managed by the State, the programmes established by the Commission are encouraging competition and inducing, wherever possible, the private sector to inject capital and expertise.

\section{- Supporting small and medium companies}

SMEs, which are often family-owned, are the main source of job creation in most of the Mediterranean partners. Their growth is often hindered by a bureaucratic environment and difficulties in obtaining finance. Simplification of administrative procedures and access to credit constitute priorities.

\section{- Developing human resources}

Training in company management is one of the top-priority areas of the actions taken by the European Union. Teaching must, in particular, rapidly satisfy the growing needs of the private sector for executives with skills in using modern management instruments, and who are above all open to the outside world.
Bearing in mind the great variety of different situations, the European Commission intends to develop actions essentially on a bilateral basis.

\section{- Improving companies' competitiveness}

The European Commission is establishing business centres in most Mediterranean partners to support companies wishing, for example, to reorganise their operational methods, introduce computerised accounting, change the range of their production, or find European partners for subcontracting.

\section{Actions in favour of an improved social balance}

Improving the living conditions of the populations, increasing the level of employment, reducing development gaps in the Euro-Mediterranean region, cushioning negative consequences in the social domain which may result from economic reforms, as well as encouraging programmes to help the poorest sections of the population, are all themes of the Barcelona Declaration. Thus, in respect of bilateral cooperation, the European Commission is financing a whole range of projects in the area of job creation, education, health and rural development, intended to address the needs of the poorest people.

The MEDA programme is aimed, specifically, at:

- improving fundamental social services, particularly in the fields of basic education and health care;

- job creation;

- enhancement of public services;

- reducing gaps between urban and rural populations;

- protecting the environment;

- improving water supply. 


\section{The contribution of the regional partnership}

Under the work programme arising from the Barcelona Conference, the economic dialogue led, in 1996, to the organisation of several ministerial conferences on tourism, industry, the information society, energy, fishing and water management. Each of these meetings led to joint policy principles in the sector concerned, and allowed an exchange of ideas and experience. In most cases, the conferences led to the establishment of permanent dialogue structures, such as, for example, the Euro-Mediterranean Energy Forum, or the Euro-Mediterranean Information System on expertise in the water field. Joint projects of common interest may also be approved, as a complement to the cooperation actions developed at bilateral level.

Several meetings of government experts also contributed to the regional dialogue: development of small and medium-sized companies, statistics, maritime transport, science and technology. In the statistics sector, following two meetings of the Directors General, a regional programme of cooperation in favour of the Mediterranean partners (MEDSTAT, 20 million Ecu) was established in order to obtain comparable and reliable data which could rapidly be used by public and private sector decision-makers.

In addition, economic and financial cooperation has mobilised private operators. Several meetings between bodies playing a similar role in each of

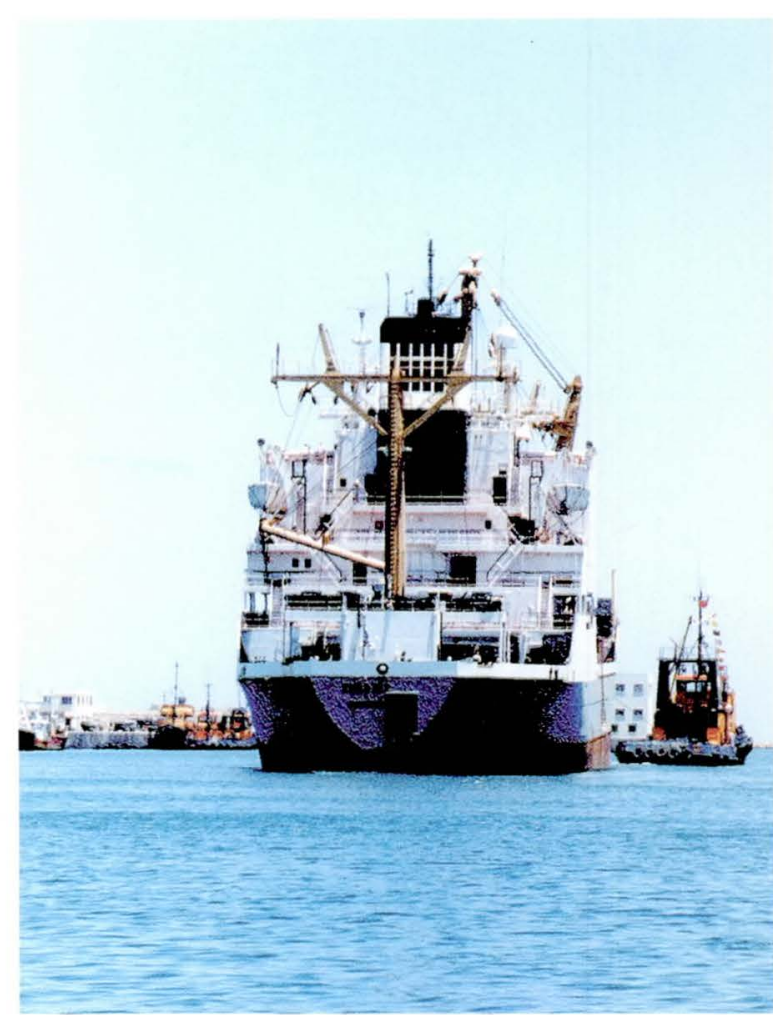

Maritime transport is one of the fields for regional Euro-Mediterranean cooperation.

the partner countries took place, or are planned, between industrial federations, banks, Chambers of Commerce, trade fairs, export promotion organisations and economic institutes. Following these meetings, and as a complement to the networks constituted between governmental organisations, several networks are currently in the process of being formed. The goal is to facilitate mutual understanding, dialogue and transfer of knowledge. The establishment of electronic communication networks and training projects in such areas is encouraged. 


\title{
ISRAEL AND JORDAN: COMMON MANAGEMENT OF HYDRAULIC RESOURCES
}

\begin{abstract}
Although, to the north of the Mediterranean, water supply poses no substantial problems, to the south, nearly one third of the population does not have sufficient drinking water. Demographic growth, urbanisation and industrialisation will inevitably lead to a rapid increase in demand for water. In the Near East, water shortage is already a reality.
\end{abstract}

In addition to the ecological aspect there is also the geo-political dimension of water control. Nearly 20 projects related to the sharing of the water of the Jordan River have been devised over the past 50 years. Only a common policy to manage resources can lead to a "hydraulic order" respecting the interests of each country. This is the logic favoured by Israel and Jordan in adopting arrangements for common management of the hydraulic resources, included in the Peace Treaty signed by the two countries in October 1994.

The European Union, which supports the peace process in the Middle East, is contributing 4 million Ecu to studies relating to the various constructions planned in the Israeli-Jordanian Peace Treaty. These studies were begun in mid-96, and will be finalised during the second half of 1997.

The Israeli-Jordanian Peace Treaty establishes a joint committee for water, and provides for the building of several constructions in the Jordan Valley to increase Jordanian hydraulic potential. In the main, these constructions extend water storage capacity and the Jordanian distribution network, through:
- the construction of a dam to divert and store water from the Yarmook River, and the establishment of several reservoirs along the Jordan:

- reinforcing of the Jordanian hydraulic distribution network, through increased capacity of the King Abdullah canal, which runs parallel to the Jordan Valley over $110 \mathrm{~km}$;

- construction of new waste water treatment installations; Israel and Jordan have also undertaken not to discharge untreated waste water into the Yarmuk and Jordan.

Supplying drinking water to Amman, where $40 \%$ of the Jordanian population live, constitutes one of the toppriority goals. By drawing $2 / 3$ of its consumption from the water table, the Jordanian capital is, effectively, using up its "water capital". The goal is to convey to Amman, directly from the Jordan, a proportion of the 30 million $\mathrm{m}^{3}$ that Israel is undertaking to deliver to Jordan under the Peace Treaty. It is also planned that the town of Irbid, in the north of the country, should be better supplied with water.

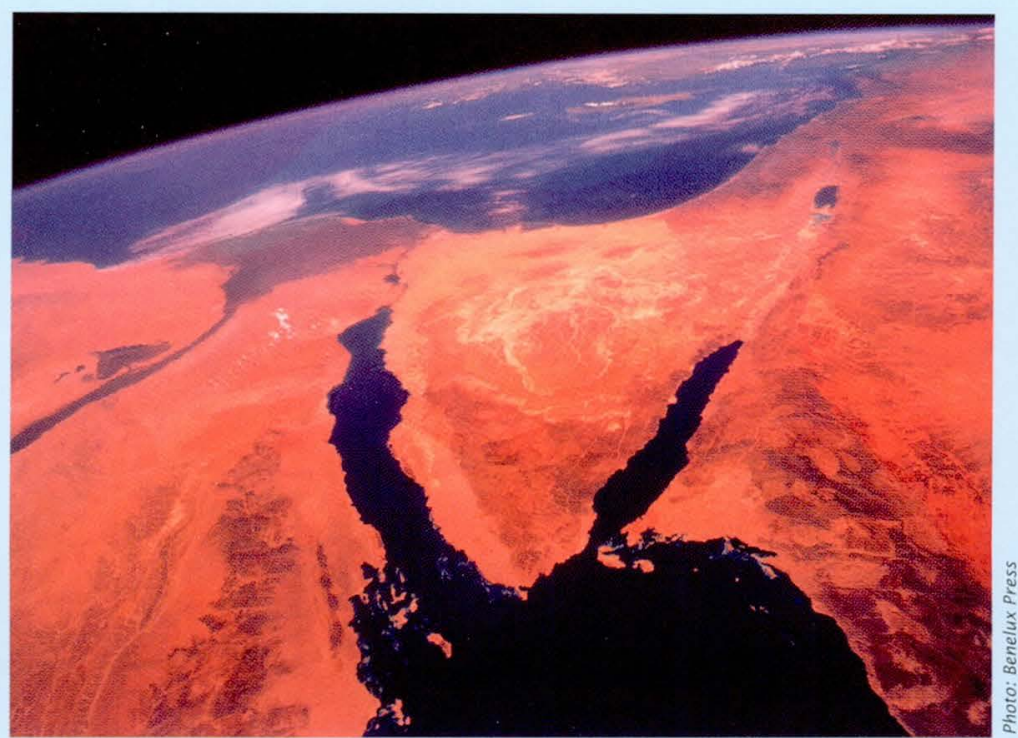

Satellite-photo of the Sinaï peninsula. In the foreground the Red Sea, in the background the Mediterranean. 


\section{NORTH AFRICA - EUROPE GAS PIPELINE}

This installation, which extends over 1370 kilometres between Hassi R'Mel (Algeria) and Cordoba (Spain), including a $525 \mathrm{~km}$-long section in Morocco, and $45 \mathrm{~km}$ under the Strait of Gibraltar, has been operational since 1996, and constitutes the most spectacular example of the economic binding of North Africa to the European Union.

After the Algerian and Moroccan sections, the Spanish section of the gas pipeline was opened on 10 December 1996. Financing by of the European Union, in the form of loans by the European Investment Bank (EIB), amounts to 638 million Ecu, including 200 million for the Algerian section, and approximately 160 million for the Moroccan part. The gas pipeline will transport annually 6 billion cubic metres of natural gas to Spain, and 2.5 billion to Portugal. For its part,

Morocco will receive 1 billion cubic metres, which will enable the national electrical energy production and chemical industry to be developed. Several joint Moroccan-European companies were constituted for the construction and operation of the gas pipeline. Thanks to this installation, hundreds of North African technicians and workers have acquired a very high level of expertise. It is a concrete illustration of the economic partnership.

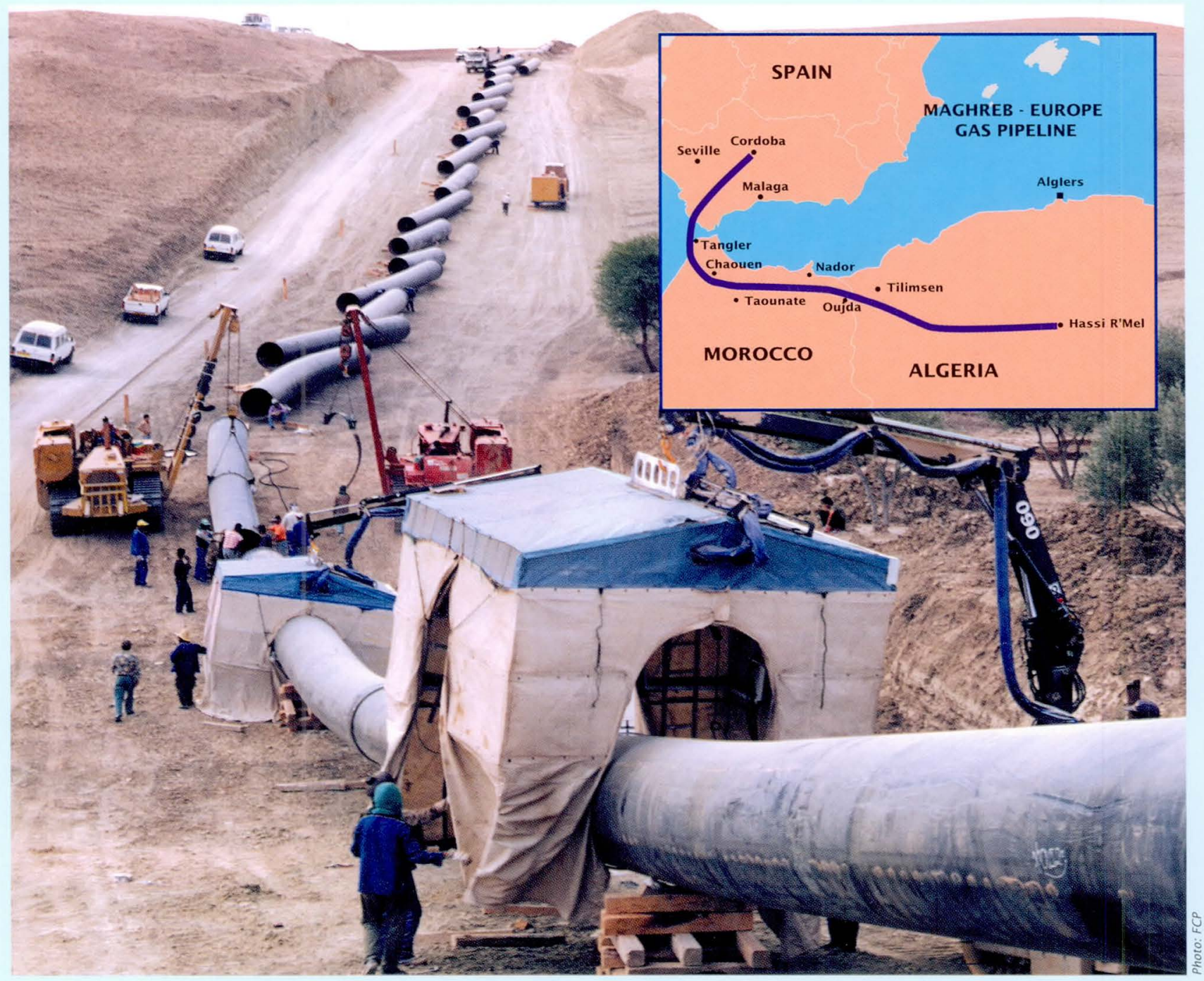

Construction of the Maghreb-Europe Gas Pipeline 


\section{Strengthening the links between civil societies}

\section{Actions to encourage improved mutual understanding}

In order to make a reality of the concept of cultural partnership as an instrument for improved understanding between peoples, the European Commission places the emphasis on simple and concrete themes:

- The organisation of joint cultural events. These relate to the various forms of artistic expression through artistic events, festivals, tours, exhibitions and seminars. Their common thread is the search for a genuine encounter between those active in the cultural field.

The past years have seen a significant growth in cultural exchanges between Europe and all its Mediterranean partners. In Fès, Tunis, Istanbul and Beirut, meetings between musicians, painters, film-makers and writers from both sides of the Mediterranean have increased. These people are thus contributing, in a very real way, to rapprochement between peoples. This process is particularly well illustrated in Syria.

In March 1996, Damascus and Aleppo staged the fourth European Film Festival. Eighteen films presented by nine European countries enabled the Syrian public to find out about the way the comic European cinema, which constituted the festival's theme, has developed during the century.

In the musical field, the success in 1995 of the first jazz festival - "Jazz Caravan" -, which had been organised by the European Commission with the support of the European Cultural institutes and centres, encouraged the European Commission to repeat this event in June 1996. With 10 groups, bringing together European and eastern musicians, "Jazz Caravan" gave some 30 concerts over 20 days in Damascus and Aleppo, and also, for the first time, in Amman, Jordan.

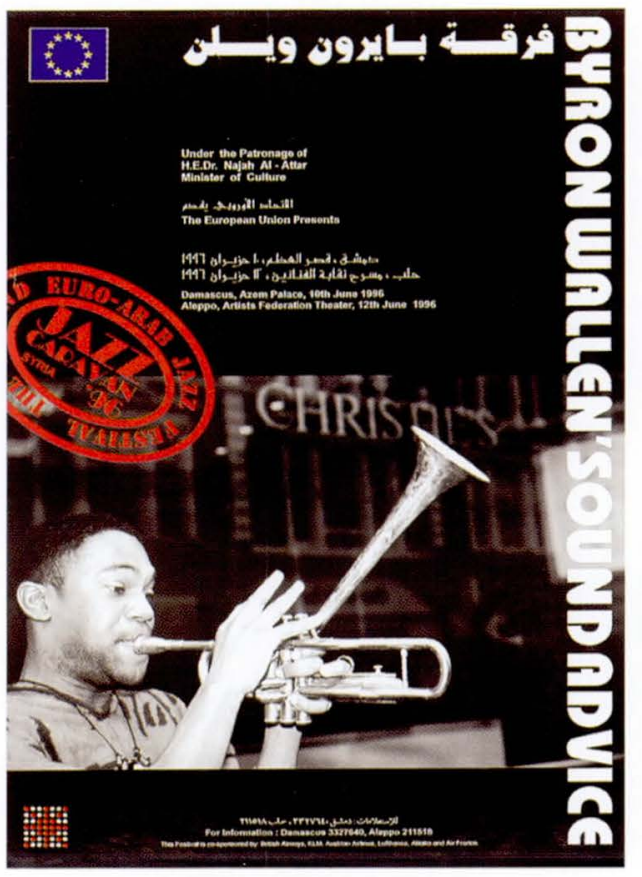

In June 1996 the "Jazz Caravan" festival visited Damascus in Syria

Another "first" greeted as an artistic event was the visit to Damascus, in October 1995, of the Chamber Orchestra of the European Union, which used this visit to stage a workshop with the students of Damascus Musical Conservatory.

Lastly, a permanent exhibition on SyrianEuropean archaeology, financed by the European Union, allows the results of the archaeological work undertaken jointly by European and Syrian specialists to be discovered. This exhibition, which is accompanied by a catalogue published in several languages, and notably in Arabic, presents the Syrian cultural heritage from its origins until the present day, as well as the elements of a joint past shared by Europe and Syria.

- Protection and presentation of the common cultural heritage, according to the guidelines devised during the Euro-Mediterranean Conference of ministers of culture held in April 1996 in Bologna.

In their joint declaration, the Ministers adopted four orientations for cultural heritage preservation projects:

- knowledge of the heritage through distribution of information, raising of the awareness of the public and of decision-makers, compilation of 
registers of heritage, expertise and techniques;

- Strengthening of heritage policies through exchanges of experience;

- Training in the professions of heritage and cultural animation;

- Improved presentation of heritage through listing and networking of museums, galleries and historical sites used as scenic locations, together with promotion of high-quality tourism.

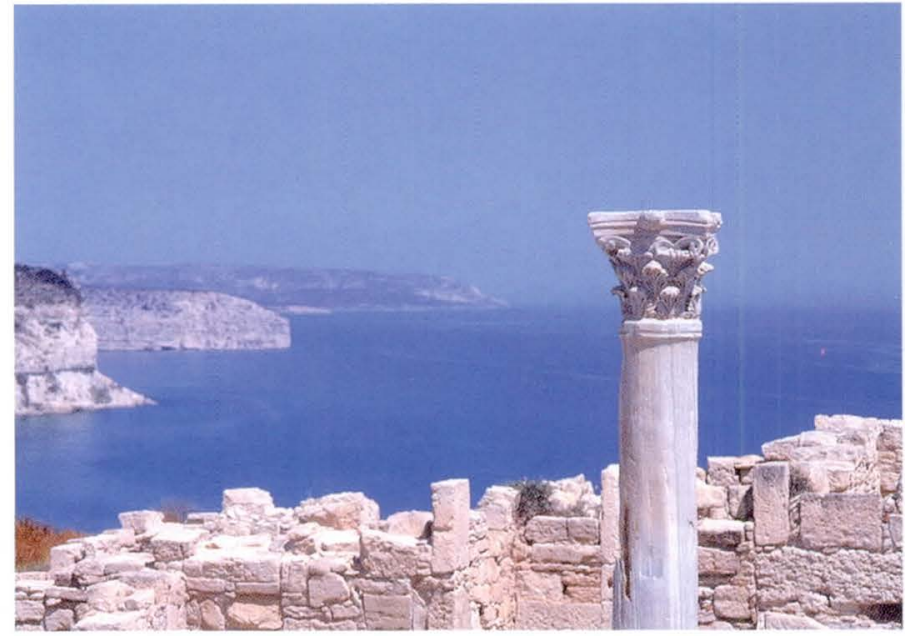

Preservation of cultural heritage is one of the partnership's goals.

On the initiative of the European Commission, in September and December 1996, the representatives of the 27 Ministries of Culture of the countries of the European Union and the Mediterranean partners, together with cultural heritage experts, met in Brussels to identify and propose 17 regionally-based projects bringing together the largest possible number of EuroMediterranean partners.

The European Union supports Euro-Mediterranean cultural projects on two levels: on a bilateral level when it concerns projects of national interest presented by the national authorities or civil society, and on a regional level when it concerns projects of common interest not previously covered by bilateral projects, and setting up a genuine exchange of expertise and a lasting dialogue between participants.

\section{Development of exchanges between civil societies: the programmes of decentralised cooperation}

The Barcelona Conference acknowledged "the essential contribution" of civil society to the EuroMediterranean partnership. This is a fundamental political development which gives an increased and acknowledged dimension to this method of cooperation. Although the Euro-Mediterranean partnership is initiated by the States, it is the citizens who will give it its true measure. Its dynamics depend

on the ability to extend beyond official confines, to mobilise regions, and economic, political, social and cultural agents, together with associative networks. The Euro-Mediterranean partnership must be able to use all agents in civil society, by increasing opportunities for joint work. In order to achieve this, programmes for decentralised cooperation constitute a major element.

These programmes seek to encourage participation, and the taking of initiatives and responsibilities by key groups in civil societies - local authorities, universities, media bodies - and to promote between them contacts, understanding, cooperation and concrete expressions of feelings of interdependence. The actions undertaken must enable Euro-Mediterranean cooperation networks to be formed between towns (Med-Urbs), universities (Med-Campus) and media professionals (Med-Media). The programmes grant financial support for the creation of networks for exchange of expertise and experience.

After a period of approximately 2 years devoted to the upgrading of their management systems, the Med-Campus, Med-Media (Training) and Med-Urbs programmes were relaunched by the European Commission in April 1998. 


\section{ADDRESSES}

\author{
Head Office of the European Commission : \\ Directorate General 1 B External Relations \\ Directorate for the South Mediterranean, \\ Middle and Near East \\ Rue de la Loi, 200 \\ 1049 Brussels - Belgium
}

Fax: (32 2) 2990204

Delegation of the European Commission in Algeria

Rue Larbi Alik, 7

Hydra

16035 Algiers

Tel.: (213 2) 692170

Fax: (213 2) 691063

Delegation of the European Commission in Cyprus

Iris Tower

8th Floor, Agapinor Street

1076, Nicosia

Tel.: (357 2) 769202

Fax: (357 2) 768926

Delegation of the European Commission in Egypt

6 Ibn Zanki Str.

Zamalek

Cairo

Tel.: (202) 3407409

Fax: (202) 3400385

Delegation of the European Commission in Israel

The Paz Tower

31-35 Bezalel Street

Ramat Gan 52521

Tel.: (972 3) 6137799

Fax: (972 3) 6137770

Delegation of the European Commission in Jordan

Al Jahez Śtreet No. 15

opposite Arab Potash Company

Shmeisani, Amman

Tel.: (972 6) 5668191

Fax: (972 6) 5686746

Delegation of the European Commission in Lebanon

Centre Saint Paul

Bloc B, 2ème étage

Jounieh

Fax: (961 9) 937154
Delegation of the European Commission in Malta

Villa "The Vines"

51 Ta' Xbiex, Sea Front

Ta' Xbiex MSD 11

Malta G.C.

Tel.: (356) 344895

Fax: (356) 344897

Delegation of the European Commission in Morocco

2 bis, avenue de Meknès

Rabat

Tel.: (212 7) 761248

Fax: (212 7) 761156

Delegation of the European Commission in Syria

Chakib Arslane Street

Abou Roumaneh

Damascus

Tel.: $(963$ 11) 3327640

Fax: (963 11) 3320683

Delegation of the European Commission in Tunisia

21 avenue Jugurtha

BP 143, Cité El Mahrajene

1082 Tunis

Tel.: (216 1) 788600

Fax: $(2161) 788201$

Representation of the European Commission in Turkey

Ugur Mumcu Caddesi No. 88

4th Floor, 06700 Gaziosmanpasa

Ankara

Tel.: (90 312) 4376843

Fax: (90 312) 4466737

Representative of the European Commission for the West Bank and Gaza

5. Sheikh Hussam Eddin

Jarrallah Street

Sheikh Jarrah

Teli:i $(9722) 5326341$ 
Already published :

The European Union and the Palestinians (French, English and Arabic) Barcelona Declaration (French and English)

MEDA-Democracy Programme (French, English and Arabic)

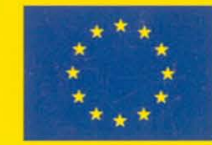

European Commission

Directorate General 1B External Relations

Rue de la Loi 200

B-1049 Brussels

Fax: +32 (2) 2990204 